\title{
PERAN ORANG TUA DALAM MENDUKUNG KREATIVITAS BELAJAR MATEMATIKA ANAK USIA DINI DI MASA PANDEMI COVID-19
}

\author{
Euis Fajriyah \\ STAI Ma'had Ali, evisfajriyah@gmail.com, Cirebon, Indonesia
}

\begin{abstract}
ABSTRAK
Pandemi Covid-19 berdampak pada semua sektor, salah satunya adalah sektor Pendidikan. Kegiatan belajar mengajar yang biasanya dilakukan di sekolah, kini harus dilakukan di rumah. Berbagai cara dilakukan oleh lembaga pendidikan anak usia dini, mulai dari Pembelajaran Jarak Jauh (PJJ) hingga pemberian tugas di rumah agar pembelajaran dapat berlangsung dengan baik. Pembelajaran matematika anak usia dini sangat penting dilakukan meskipun dalam masa pandemi. Anak usia dini dapat melakukan kegiatan matematika sambil bermain di rumah masing-masing. Hal ini akan mengeksplorasi kreativitas anak melalui pembelajaran yang menyenangkan. Kegiatan belajar di rumah tentu memerlukan pendampingan orang tua. Penelitian ini menggunakan metode kualitatif melalui observasi, dokumentasi, dan wawancara. Hasil penelitian memberikan informasi bahwa orang tua memiliki peran penting dalam keberlangsungan kegiatan kegiatan pembelajaran yang menyenangkan dan bermakna bagi anak usia dini sehingga anak dapat mengeksplorasi kreativitasnya dalam belajar matematika di masa pandemi Covid-19. Kegiatan pembelajaran matematika yang menyenangkan dan bermakna dapat dilakukan melalui permainan atau pengenalan bendabenda nyata yang ada di lingkungan anak. Kegiatan tersebut dapat membuat anak merasa nyaman dalam belajar dan tujuan pembelajaran dapat tercapai.
\end{abstract}

Kata kunci: Anak usia dini; Kreativitas belajar matematika; Pandemi Covid-19; Peran orang tua

\section{PENDAHULUAN}

Indonesia dihadapkan pada masa pandemi Covid-19 sejak Maret 2020 lalu. Kegiatan-kegiatan publik kini beralih menjadi kegiatan dimana pusat utamanya berasal dari rumah. Realitas ini menjadi baru dalam dunia pengajaran khususnya di lingkup pendidikan anak usia dini (PAUD) (Mundi \& Nurkolis, 2021). Hal ini sesuai dengan kebijakan yang telah dikeluarkan Kementerian Pendidikan dan Kebudayaan (Kemdikbud) dalam menyikapi kasus pandemi Covid-19 khususnya di bidang pendidikan. Kemendikbud melakukan ber bagai cara dalam menangani masalah pendidikan di masa pandemi Covid-19, diantaranya dengan mengadakan kegiatan belajar dari rumah sebagai antisipasi penanganan pandemi Covid-19 (Kemendikbud, 2020). Berdasarkan kebijakan tersebut, peserta didik dalam hal ini anak usia dini dapat melakukan kegiatan belajar sambil bermain di rumah masingmasing. Kegiatan belajar di rumah bukan hanya menjadi tanggungjawab guru dan peserta didik, namun juga orang tua.

Anak usia dini ada pada fase perkembangan yang sangat pesat sehingga mereka cenderung meniru apa yang ada lingkungannya. Dalam hal ini orang tua 
sangat berperan penting bagi tumbuh kembang anak mereka, termasuk dalam kegiatan belajarnya. Aktivitas belajar sejatinya telah dilakukan manusia sejak mereka dilahirkan. Menurut Dahar (2011) belajar merupakan suatu proses dimana suatu organisasi berubah perilakunya sebagai akibat dari pengalaman. Sedangkan Suprihatiningrum (2013) mendefinisikan belajar sebagi suatu proses usaha untuk memperoleh perubahan perilaku tertentu sebagai pengalaman yang dilakukan dalam interaksinya dengan lingkungan yang dilakukan oleh individu secara sadar. Merujuk pada pendapat tersebut, maka belajar merupakan salah satu faktor yang mempengaruhi perkembangan anak berdasarkan pengalamannya. Dengan demikian, baik guru maupun orang tua, harus tanggap dalam mendampingi anak untuk memenuhi kebutuhan belajarnya.

Pembelajaran matematika bagi anak usia dini haruslah dikemas dengan efektif dan menyenangkan. Pembelajaran anak usia dini dilakukan dengan cara bermain (Zaini, 2015). Anak usia dini baru mulai mengenal angka maupun menghitung bendabenda yang ada di sekitarnya. Pembelajaran Matematika di tingkat pendidikan anak usia dini diberikan secara bertahap mulai dari menghitung benda-benda melalui pengalaman berdasarkan kejadian nyata atau pengamatan yang dilakukan anak-anak dalam kehidupan sehari-hari. Lisa (2018) mengutarakan bahwa pengenalan konsep matematika bagi anak usia dini disesuaikan dengan tingkat perkembangan mental anak. Hal ini senada dengan teori belajar Piaget dalam Suyadi (2010) bahwa kegiatan belajar memerlukan kesiapan dalam diri anak, dengan kata lain belajar sebagai suatu proses membutuhkan aktifitas, baik fisik maupun psikis. Kegiatan belajar anak juga harus disesuaikan dengan tahap-tahap perkembangan mental anak. Lebih lanjut, Piaget dalam Suyadi (2010) juga mengemukakan bahwa perkembangan kognitif, khususnya intelektual, merupakan proses konstruksi. Perkembangan kognitif yang dimaksud terdiri atas dua bidang, yaitu logika-matematika dan sains.

Anak melakukan kegiatan belajar disebabkan oleh sebuah dorongan, baik itu yang bersifat internal maupun eksternal. Dorongan berupa kekuatan mental inilah yang dikenal dengan motivasi. Husamah (2018) mengungkapkan bahwa peran dan fungsi motivasi bagi anak dalam belajar sangat penting, motivasi belajar anak dipengaruhi oleh beberapa faktor yaitu: (1) aspirasi (2) kemampuan (3) kondisi individu (4) unsur-unsur dinamis dalam belajar dan pembelajaran (5) upaya guru dan orangtua dalam pembelajaran.

Kelvarga sebagai lingkungan pertama dalam perkembangan pendidikan anak turut serta menentukan keberhasilan belajar seorang anak (Astuti, Rivaie, \& ibrahim, 2013). Beberapa cara dilakukan orang tua dalam mendampingi kegiatan 
belajar anak, yaitu memahami bagaimana gaya belajar anak untuk memudahkan anak dalam belajar (Ahsani, 2020).

Peran orang tua bagi pendidikan anak pada masa pandemi Covid-19 sangat dibutuhkan (Sambayu, 2021). Pembelajaran daring di masa pandemi Covid-19 membuat peran orang tua menjadi bertambah, salah satunya untuk memberikan edukasi kepada anak tentang pandemi yang sedang terjadi. Orang tua diharapkan mampu memberikan edukasi dengan membekali anak tentang informasi yang mudah dimengerti mengenai covid-19 (Ahsani, 2020). Pembelajaran daring selama masa pendemi Covid-19 memberikan ruang bagi anak dengan pendampingan orang tua untuk mengeksplorasi kreativitas belajar matematika melalui bendabenda yang ada di sekitarnya.

Kreativitas belajar anak berkaitan dengan imajinasi dan fantasi. Anak-anak yang kreatif cenderung sensitif terhadap stimulasi. Anthoni Robin dalam C.J Simister (2013) mengungkapkan bahwa keingintahuan pada anak menandakan semangat yang aktif, terbuka dan berorientasi pada pemecahan masalah serta merupakan elemen penting dari kreativitas, inovasi dan kemajuan anak-anak. Dalam tulisan ini akan dibahas mengenai peran orang tua dalam mendukung kreativitas belajar matematika anak usia dini di masa pandemi Covid-19.

\section{METODE}

Penelitian ini menggunakan metode kualitatif dengan subjek penelitian orang tua anak usia dini yang berlokasi di Desa Kedungdawa Kecamatan Kedawung Kabupaten Cirebon. Data dikumpulkan melaui observasi, dokumentasi, dan wawancara. Observasi merupakan teknik pengumpulan data melalui proses pengamatan secara langsung di lapangan (Moleong, 2013). Dokumentasi digunakan untuk mencari data berupa catatan, transkrip, buku, agenda, dan lain sebagainya (Arikunto, 2010). Terkait dengan dokumentasi, Creswell (2014) mengungkapkan bahwa dokumentasi memungkinkan peneliti untuk memperoleh bahasa dan katakata tekstual dari partisipan, dapat diakses kapan saja, menyajikan data yang berbobot, dan sebagai bukti tertulis dalam proses pentranskripan. Adapun wawancara yang digunakan berbentuk wawancara terstuktur dengan menggunakan daftar pertanyaan yang telah disiapkan dan wawancara tidak terstruktur yang dilakukan apabila jawaban berkembang di luar pertanyaan terstruktur namun masih dalam lingkup permasalahan penelitian.

\section{HASIL DAN DISKUSI}




\section{HASIL}

Berdasarkan data yang diperoleh melalui observasi, dokumentasi, dan wawancara, orang tua sangat berperan dalam melaksanakan kegiatan pembelajaran matematika anak usia dini di masa pandemi Covid-19. Orang tua mampu mendampingi anaknya untuk mengeksplorasi pengetahuan yang diterima berdasarkan pengalaman nyata secara langsung (learning by doing) melalui bendabenda di sekitarnya. Hal ini turut mendukung kreativitas anak usia dini dalam belajar matematika. Kreativitas belajar matematika diperoleh melalui kegiatan pembelajaran yang mengedepankan aktivitas bermain. Hal ini sesuai dengan temuan Bergen (2009), Özdogan (2011), Perry \& Dockett (2011), dan Mirawati (2017) bahwa konteks bermain bagi anak dalam pembelajaran matematika dapat memudahkan anak untuk memahami berbagai konsep matematika dan mengembangkan minat belajar anak.

Adapun kegiatan belajar matematika berdasarkan data yang diperoleh adalah kegiatan Little Chef. Kegiatan Little Chef dilakukan oleh Subjek 01 bersama anaknya yang berusia 6 tahun. Kegiatan ini merupakan kegiatan membuat makanan sederhana dimana anak bermain peran sebagai koki kecil dan dalam pelaksanaanya dilakukan dengan menyenangkan. Kegiatan Little Chef melibatkan benda-benda di lingkungan tempat tinggal anak. Hal ini tentu memudahkan anak dalam kegiatan belajar sambil bermain. Subjek 01 bersama anaknya membuat es krim berbagai rasa yang disukai anak-anak. Kegiatan ini memunculkan kreativitas anak, salah satunya ide-ide yang keluar dari pikiran anak tentang es krim rasa apa saja yang akan ia buat. Subjek 01 mendukung dan memberikan kesempatan pada anak untuk mengeksplorasi kreativitasnya.

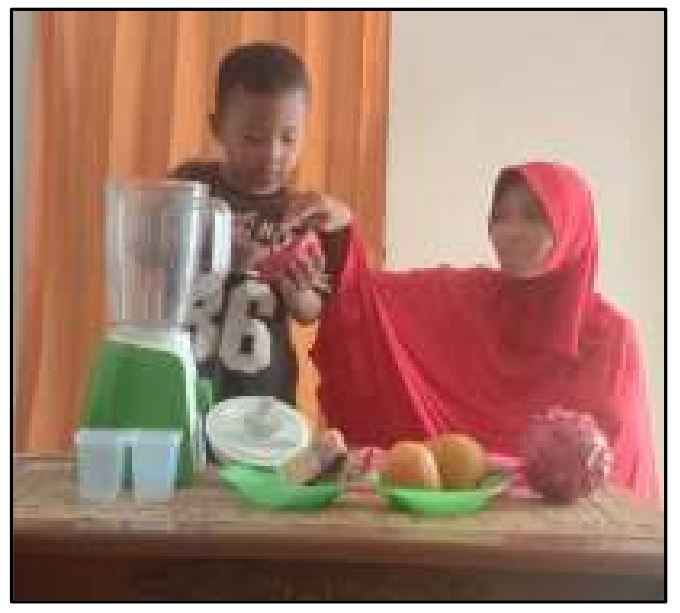

Gambar 1. Kegiatan Little Chef Subjek 01 bersama anaknya 
Adapun kemampuan matematis yang muncul dalam kegiatan Little Chef tersebut adalah sebagai berikut:

1. Mengukur

Kegiatan Little Chef memunculkan kemampuan mengukur pada anak usia dini. Dalam kegiatan ini, anak diberi kesempatan untuk mengukur bahan-bahan yang digunakan untuk membuat es krim berbagai rasa.

2. Memperkirakan

Kegiatan Little Chef memunculkan kemampuan memperkirakan pada anak usia dini. Anak diberi kesempatan untuk memperkirakan berapa banyak es krim yang ingin ia buat untuk dibagikan kepada seluruh anggota keluarga.

3. Berhitung

Kegiatan Little Chef memunculkan kemampuan berhitung pada anak usia dini. Anak melakukan proses berhitung sederhana jumlah es krim yang ia buat.

4. Mengenal Bentuk

Kegiatan Little Chef memunculkan kemampuan mengenal bentuk pada anak usia dini. Anak diberi kesempatan untuk mengenal bentuk geometri pada es krim yang ia buat.

\section{PEMBAHASAN}

Amalina (2021) mengungkapkan bahwa pembelajaran matematika untuk anak usia dini di masa pandemi Covid-19 hendaknya merupakan pembelajaran yang menyenangkan dengan mengeksplorasi hal sederhana yang dekat dengan anak atau hal yang digemari anak. Kondisi di rumah saja (stay at home) yang berlangsung dalam waktu lama seperti saat ini memberi kesempatan yang luas kepada setiap lingkup keluarga untuk memperoleh pendidikan informal. Kesempatan besar yang ada sekarang, anak memiliki banyak waktu yang berkualitas (quality time) bersama orangtua lebih banyak dari biasanya sehingga hubungan orangtua-anak dapat terjalin lebih komunikatif (Subarto, 2020). Orang tua memiliki peran penting dalam keberlangsungan kegiatan pembelajaran yang menyenangkan dan bermakna sehingga mampu mengeksplorasi kreativitas anak usia dini khususnya dalam belajar matematika di masa pandemi Covid-19. Adapun peran orang tua dalam mendukung kreativitas belajar matematika anak usia dini di masa pandemi covid-19 adalah (1) orang tua sebagai guru (2) orang tua sebagai motivator (3) orang tua sebagai fasilitator (4) orang tua sebagai director. Hal ini sesuai dengan penelitian Sambayu (2021) bahwa peran orang tua dalam kegiatan pembelajaran di era pandemi Covid-19 adalah sebagai media pembelajaran, sebagai motivator, 
sebagai makna Life Long Education, dan sebagai sarana dalam mempertahankan kehidupan yang lebih baik.

\section{KESIMPULAN}

Orang tua memiliki peran penting dalam keberlangsungan kegiatan pembelajaran yang menyenangkan dan bermakna bagi anak usia dini sehingga anak dapat mengeksplorasi kreativitasnya dalam belajar matematika di masa pandemi Covid-19. Kegiatan pembelajaran matematika yang menyenangkan dan bermakna dapat dilakukan melalui permainan atau pengenalan benda-benda nyata yang ada di lingkungan anak. Kegiatan tersebut dapat membuat anak merasa nyaman dalam belajar dan tujuan pembelajaran dapat tercapai.

\section{UCAPAN TERIMA KASIH}

Puji syukur kepada Allah SWT, atas berkah rahmat-Nya penelitian ini dapat diselesaikan dengan baik. Terima kasih kepada seluruh pihak yang telah membantu dalam penyelesaian tulisan ini.

\section{REFERENSI}

Ahsani, E. L. 2020. "Strategi Orang Tua dalam Mengajar dan Mendidik Anak dalam pembelajaran at the Home Masa Pandemi Covid-19". STAINU Purworejo: JurnalAl_Athfal, 37-46.

Amalina. 2021. "Pembelajaran Matematika Anak Usia Dini di Masa Pandemi Covid-19 Tahun 2020". Jurnal Obsesi : Jurnal Pendidikan Anak Usia Dini, 5(1), 538-548.

Arikunto, S. 2010. Prosedur Penelitian; Suatu Pendekatan Praktik. Jakarta: Rineka Cipta. Astuti, D., Rivaie, W., \& ibrahim, Y. (2013). "Analisis Peran Orang Tua dalam Meningkatkan Hasil Belajar Siswa Kelas X SMK Muhammadiyah Pontianak". (Doctoral dissertation, Tanjungpura University).

Bergen, D. 2009. "Play as the Learning Medium for Future Scientists, Mathematicians, and Engineers". American Journal of Play: The Board of Trustees of the University of Illinois.

Creswell, J. W. 2014. Research Design: Pendekatan Kualititatif, Kuantitatif, dan Mixed. Terjemahan. Yogyakarta: Pustaka Pelajar.

Dahar, R. 2011 . Teori-Teori Belajar dan Pembelajaran. Jakarta: Erlangga. 
Husamah, dkk. 2018. Belajar \& pembelajaran. Malang: UMM Press.

Kemdikbud. 2020. Surat Edaran: Pelaksanaan Pendidikan dalam Masa Darurat Covid19.

Lisa. 2018. Pengenalan Berhitung Matematika Pada Anak Usia Dini. Vol 1 (2), 1-14.

Mirawati. 2017. "Matematika Kreatif: Pembelajaran Matematika Bagi Anak Usia Dini Melalui Kegiatan Yang Menyenangkan dan Bermakna". PEDAGOGI: Jurnal Anak Usia Dini dan Pendidikan Anak Usia Dini, 3 (3a).

Moleong, L. 2013. Metode Penelitian Kualitatif. Bandung: Remaja Rosda Karya.

Mundi, \& Nurkolis. 2021. "Keefektivan Kebijakan E-Learning berbasis Sosial Media pada PAUD di Masa Pandemi Covid-19". Jurnal Obsesi : Jurnal Pendidikan Anak Usia Dini, $5(1), 212-228$.

Özdogan, E. 2011. "Play, Mathematic and Mathematical Play in Early Childhood Education". ELSEVIER: Procedia Social and Behavioral Sciences 15, 3118-3120.

Perry, B. \& Dockett, S. 2011 . Playing With Mathematics: Implications from The Early Years Learning Framework and The Australian Curriculum. Mathematics Traditions and New Practices: Aamt \& Merga.

Sambayu, dkk. 2021. "Peran Orang Tua Terhadap Pembelajaran Daring Masa Pandemi Virus Covid-19 Di Desa Lestari Kecamatan Buntu Pane". Jurnal Pengabdian Kepada Masyarakat, 1(1), 144-150.

Simister C.J. 2013. Anak-Anak Cemerlang. Jakarta: Serambi.

Subarto, S. (2020). "Momentum Keluarga Mengembangkan Kemampuan Belajar Peserta Didik di Tengah Wabah Pandemi Covid-19". 'ADALAH, 4(1), 1-6.

Suprihatiningrum, J. 2013. Strategi Pembelajaran: Teori dan Aplikasi. Yogyakarta: ArRuzz Media.

Suyadi. (2010). Psikologi Belajar Anak Usia Dini. Yogyakarta: PEDAGOGIA.

Zaini, A. 2015. "Bermain sebagai Metode untuk Pembelajaran Anak Usia Dini". Thufula: Jurnal Inovasi Pendidikan Guru Raudhatul Atfal, 3(1), 118-134. 